\title{
Flood insurance rate map for non-structural mitigation
}

\author{
Rasyikin Roslan ${ }^{1, *}$, Rohayu Che Omar ${ }^{1}$, M. Hara ${ }^{2}$, B. Solemon ${ }^{1}$, and I.N.Z Baharuddin ${ }^{1}$ \\ ${ }^{1}$ Institute of Energy Infrastructure, Universiti Tenaga Nasional,Jalan IKRAM-UNITEN, 43000 Selangor, Malaysia \\ ${ }^{2}$ VisionTech Incorporated (VTI), 2-1-16 Umezono, Tsukuba, Ibaraki 305-0045, Japan
}

\begin{abstract}
December 2014 flooding in Kelantan river basin caused severe damage to economic and social infrastructure and dealt a serious blow to Kelantan state economies. Mitigation of flood disaster can be successful only when detailed knowledge is obtained about the vulnerability of the people, buildings, infrastructure and economic activities in a flood risk area. Therefore, to identify a community's flood risk, pre-disaster financial instrument will be introduced as non-structural mitigation measures know as flood insurance rate map. This instrument will be developed based on geospatial technology using satellite images, topographic surveys, cadastral map, type of community building such as residential or commercial and households' income. Flood hazard maps and flood insurance rate map will provide the flood risk zone and flood insurance rate and premium coverage for the affected community. In additions it helps to determine the type of flood insurance coverage is needed since standard homeowners' insurance doesn't cover flooding. Flood insurance rate map will provide affordable insurance for property owners, based on the lower the degree of risk state in flood hazard map, the lower the flood insurance premium. These insurance rate map are valuable to communities because it creates safer environments by reducing loss of life and decreasing property damage, allows individuals to minimize post-flood disaster disruptions and to recover quicker.
\end{abstract}

\section{Introduction}

High impact floods have become a virtually annual experience in Malaysia, yet flood insurance has remained a grossly neglected part of comprehensive integrated flood risk management. An argument for enhanced flood insurance penetration as part of comprehensive flood risk management in Malaysia could be established. Managing the flood risk need to decrease future losses and ease the recovery of affected populations, vulnerable people must become more resilient to flood hazards. Insurance is one possible method that people can use to decrease personal losses from flood hazard events and enable them to recover more quickly [1-3]. Many researchers believe that if insurance can represent the actual degree of risk in each policy and employ advocacy and mitigation programs, financial losses may be able to be reduced [3]. In this way, insurance companies could represent high risk flood hazard areas with more expensive insurance premiums than lower risk flood hazard area. This may discourage people from living in unsafe areas and make the inhabitants more aware of the potential risk because it personalizes the risk. With an improved understanding of the hazardousness of properties and a decrease in losses from natural hazards, communities can become more resilient by discouraging development in hazard prone areas [4].

This study need to be highlight because the relationship between insurance, disaster losses, and vulnerable populations related to flood prone area is not well understood [3]. An insured property damaged by flood can be replaced quickly without much financial stress to the government [5]. A community with extensive flood insurance can rebuild faster after a flood [6-8] described flood insurance as serving the purpose of reducing the economic impact of individual losses by arranging for the transfer of all or part of the loss to others who share the same risk. Similarly, [9] conceive flood insurance as a private mitigation measure which reduces financial consequences for an individual once a flood occurs. The demand for insurance is driven by an individual's knowledge of potential risk, which will transfer the risk to an insurance company to effectively absorb and diversify the risk.

To overcome this issue pre-disaster financial instrument will be introduced as non-structural mitigation measures know as flood hazard maps and flood insurance rate map $[8,10,11]$. Geo spatial technology will be used to produced Flood hazard maps and flood insurance rate map. Flood hazard maps and flood insurance rate map will provide the flood risk zone, level of vulnerability (including building and agricultural vulnerability), household income and flood premium coverage for the affected community. In additions it $\mathrm{m}$ degree of risk state in flood hazard map, the lower the flood insurance premium. These predisaster financial instruments will reduce the socioeconomic impact of disasters by promoting the purchase and retention of risk insurance in general, and National Flood Insurance in particular after it be introduced as tools in land use planning process.

\footnotetext{
*orresponding author: vegegrout@gmail.com and rasyikin@uniten.edu.my
} 


\section{Methods}

Flood hazard map and flood risk map are develop based on hazard assessment, exposure assessment, vulnerability assessment, risk assessment adapted from [12-15] as Figure 1. While, insurance rate map is develop based on relationship between the spatial variability of insurance, socio economic vulnerability, and natural hazard losses during flood event. The technique to produce insurance rate map in these papers are based on risk assessment as Figure 1. but are modified to promoting resilient economies by exploring insurance potential based on socio-economic survey and damaged estimation integrated with exposure assessment using land use map, census data and cadastral map and satellite imagery with the probability of flood in the study area as Figure 2.

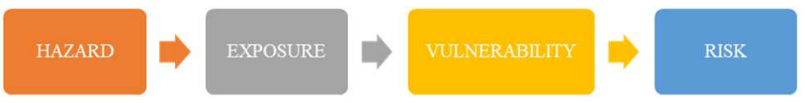

Fig. 1. The assessment technique based on risk assessment concept adapted and modified from [12-15].

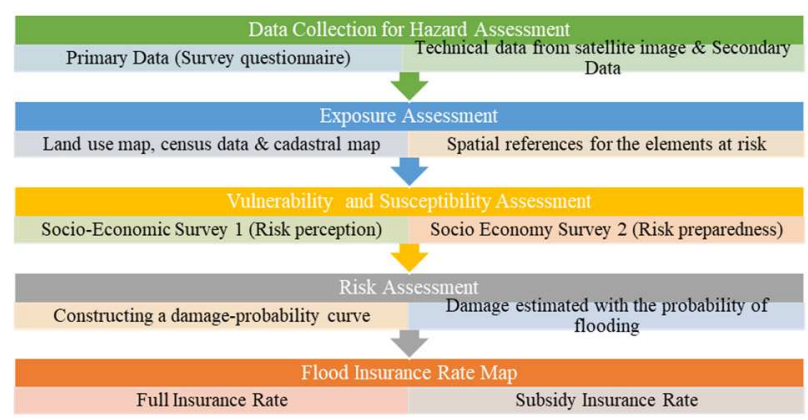

Fig. 2. Methodology to produce flood insurance rate map based on risk assessment concepts.

\subsection{Flood hazard and exposure assessment}

Hazard assessment in these study is based on Tanah Merah and Pasir Mas flood maps (producing by Drainage and Irrigation Department (DID)) and integration of satellite imagery such as ALOS 2 from December 2014 and name as modified flood map. Modified flood maps are overlaid on land-use maps (land use map from Urban and Rural Planning Department and Agricultural Department), census data, and cadastral map to form the basis of the exposure assessment. Exposure assessment objective is to provide spatial references for the elements at risk of being flooded, such as residential, non-residential uses, commercialization area, agricultural uses and people. The asset which are element at risk or in negative consequences or vulnerable to be harmed by flooding are later considered as susceptibility to flooding.

The susceptibility rate to flooding in these researches are estimate by socio-economic surveys (risk perception and risk preparedness questionnaire survey). The measurement in the survey form are related to (i) individual and collective preparedness based on a scale from 1 (lowest value) to 5 (higher value); (ii) past experience of floods and focused on the degree a previous flooding have caused financial damage and based on scale 1 (no financial damage) and 5 (considerable damage) and the amount of damage are expected; (iii) perceived effectiveness of countermeasures which respondents were asked to express their opinion of effectiveness in relation with the specific measures adopted at local level and are scale from 1 (agree) and 5 (disagree); (iv) insurance based on agree and disagree and affordable to pay the insurance coverage in case of damages for managing the future flood; and (v) socio demographic variable based on age, gender, job related activities or living near or in flood plain area. The survey design is based on [16-19].

Risk assessment consists of constructing a damageprobability curve or flood risk curve. This usually is used to calculate the expected annual damage, which is the most frequently used measure of flood risk [17]. In this study the expected annual damage is calculate based on data from socio-economic survey which can be obtained from past experience of floods and focused on the degree a previous flooding has caused financial damage $[20,21]$ and $[13,22]$. All data are overlay and classified based on risk value index to produce elements at risk in total. These risk map are used to produce flood insurance rate map.

\subsection{Urban element at risk}

Urban element at risk have been identified by overlaying the cadastral and population or census with modified flood map. The urban elements are classified as residential, commercial and agricultural area and are reflected from land use map. Total urban element at risk are calculate for Tanah Merah are 27594.118 ha and Pasir Mas 545645.799 ha. Figure 3 show the total urban element at risk.

The type of damage considered are the direct cost of cleaning and damage to the building either residential, commercial or agricultural land. In questionnaire survey, the damage for Pasir Mas and Tanah Merah for residential, commercial and agricultural land range between RM 10,000 to RM 150,000.00. The result of estimated damage for residential, commercial and agricultural land as Table 1. The higher the estimation damage, the higher the risk. 


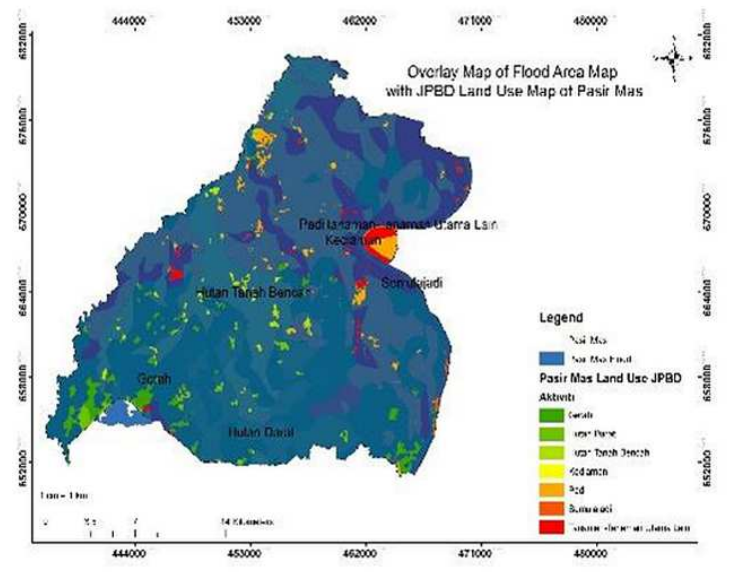

(a) Pasir Mas

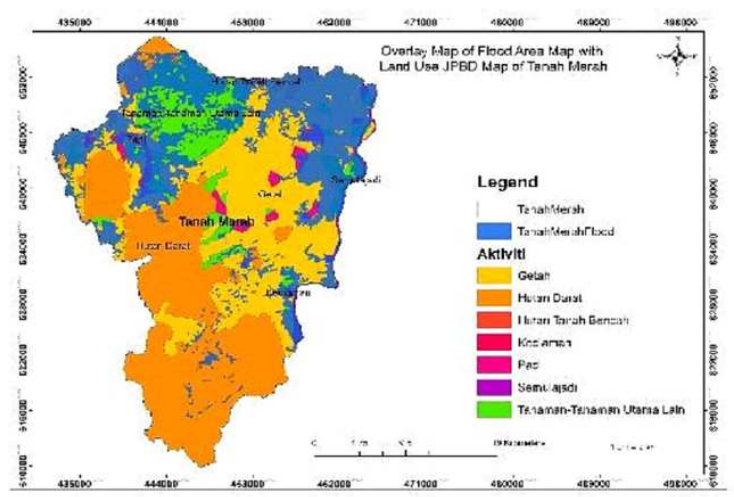

(b) Tanah Merah

Fig. 3. Total urban element at risk for Tanah Merah (27594.118 ha) and Pasir Mas (545645.799 ha).

Table 1. Estimation damage for residential, commercial and agricultural land.

\begin{tabular}{|l|c|c|c|}
\hline \multicolumn{1}{|c|}{ District } & $\begin{array}{c}\text { Residential } \\
\text { (RM) }\end{array}$ & $\begin{array}{c}\text { Commercial } \\
\text { (RM) }\end{array}$ & $\begin{array}{c}\text { Agricultural } \\
\text { (RM) }\end{array}$ \\
\hline Tanah Merah & 70,000 & 150,000 & 80,000 \\
\hline Pasir Mas & 90,000 & 100,000 & 95,000 \\
\hline
\end{tabular}

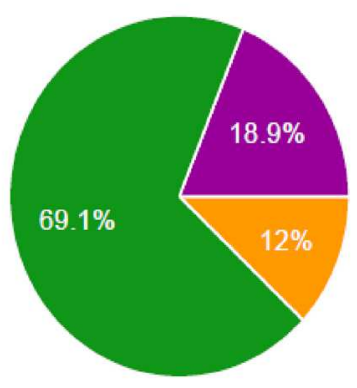

Fig. 4. Respondent affordable and willingness to pay

Flood insurance rate map are calculate based on adoption of insurance system concept using quantitative approach and it calculate only the direct damage. The estimation damage and the affordable to pay the insurance coverage from the questionnaire survey are used to calculate the insurance rate map. Figure 4 shows that the $69.1 \%$ of respondent affordable to paid RM
50.00 per month, $12 \%$ of respondent affordable to paid RM 300 and $18.9 \%$ not willing to pay.

\subsection{Flood hazard map and flood risk map}

Exposure assessment is a step to produce flood inundation map or flood map. Exposure assessment objective is to provide spatial references for the elements at risk of being flooded, such as residential, nonresidential uses, commercialization area, agricultural uses and people. Flood map are develop using satellite imagery observation data occurring from ALOS2/PALSAR 2 before the flooding (13/9/2014) and $(11 / 10 / 2014)$, during the flooding $(26 / 12 / 2014)$ and after the flooding (07/01/2015) to assess the area that exposure to 2014 flooding and inland waters of Kelantan area extracted to produce flood hazard map shows as Figure 5.
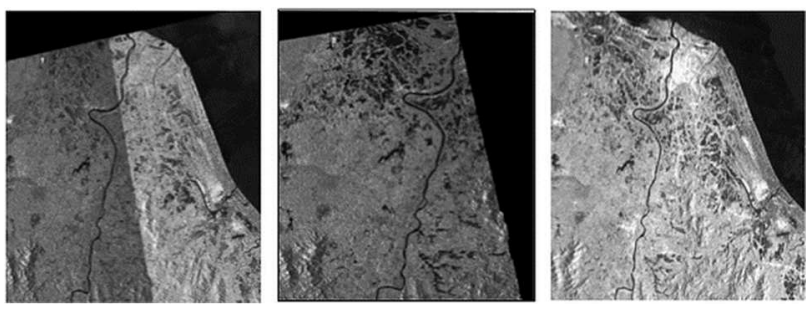

ALOR PALSAR 2

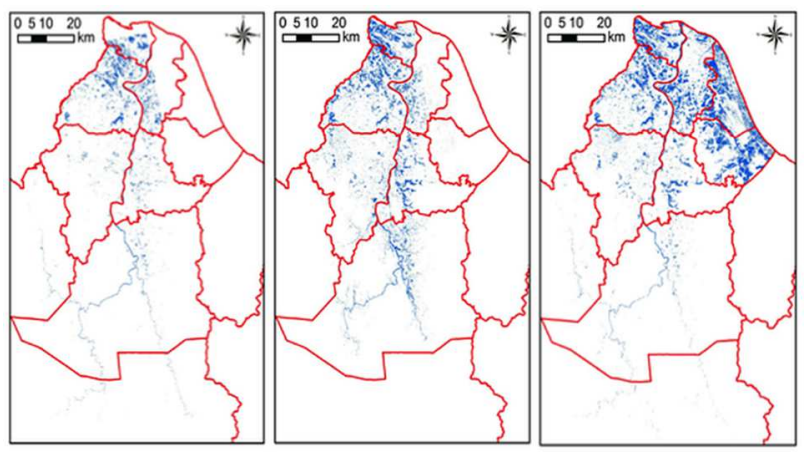

Fig. 5. Extracted inland water before flood, during and after flood using ALOS PALSAR 2 to developed exposure flood area for flood hazard map.

After producing flood hazard map, DEM data called GDEM are generated from the ASTER data observed by EOS satellite to produce level of flood map and to differentiate between flood exposure area with river or lake and the inland water (such as paddy field) before the flood (Figure 6).

Aster GDEM identified the feature of river and lakes as green color, the inland water before flood as light blue and the flood area as blue (Figure 6). Last step of the process is to produce vulnerability, susceptibility and risk map. Geographic information system platform is use in this step. Historical data of flood event for 10 years are integrate using determination concepts and overlay with flood event from ALOS PALSAR2 from $26 / 12 / 2014$ and $07 / 1 / 2015$ imagery to produce flood occurrence frequency distribution map as Figure 7. 

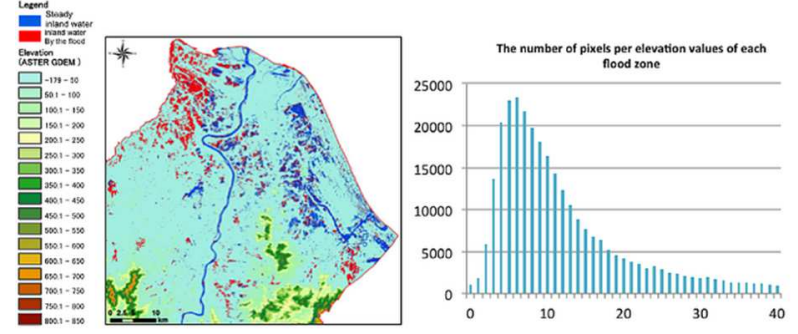

Fig. 6. Generating of DEM data from ASTER GDEM to produce level (height) of flood map and differentiate between flood exposure area with river or lake and the inland water (such as paddy field) before the flood event.

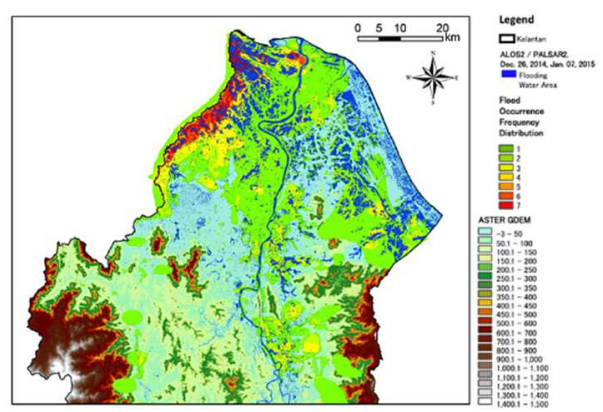

Fig. 7. Flood occurrence frequency distribution map and historical data overlay with flood event from ALOS PALSAR2 from 26/12/2014 and 07/1/2015.

Flood occurrence frequency distribution map that are knows as vulnerability and susceptibility flood map are analysis together with socio economic survey data for risk perception and preparedness in geographic information system (GIS) platform to produce flood risk map (Figure 8). The measurement in the survey form that related to individual and collective preparedness, past experience of floods and focused on the degree a previous flooding has caused financial damage and the amount of damage are expected are used as socio economic survey data.

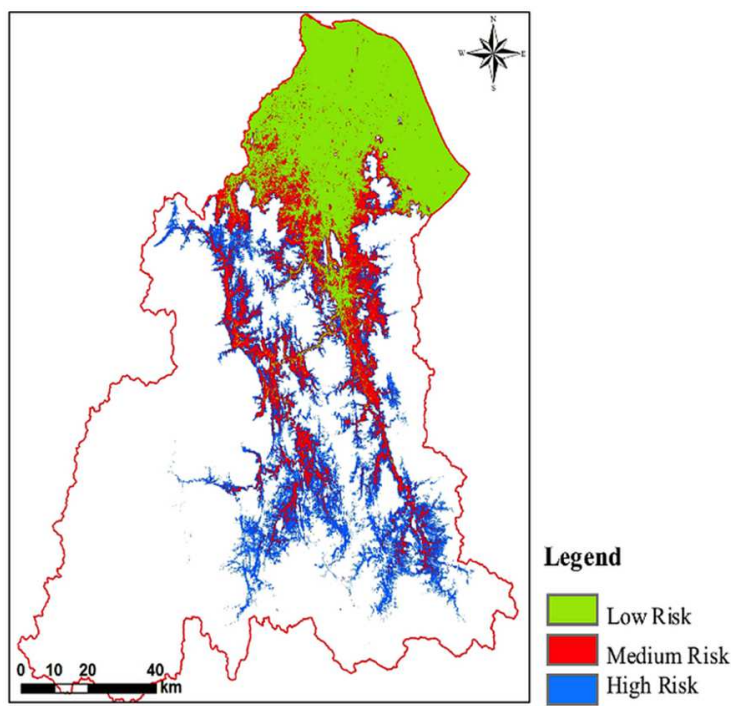

Fig. 8. Kelantan flood risk map.

\section{Flood insurance rate map}

The type of damage considered are the direct cost of cleaning and damage to the building either residential, commercial or agricultural land. In questionnaire survey, as example the damage for Pasir Mas and Tanah Merah for residential, commercial and agricultural land range between RM 10,000 to RM 150,000.00. The result of estimated damage for residential, commercial and agricultural land shows as Table 1. The higher the estimation damage, the higher the risk.

Flood insurance rate map are calculate based on adoption of insurance system concept using quantitative approach and it calculate based on the direct damage. The estimation damage and the affordable to pay the insurance coverage from the questionnaire survey are used to calculate the insurance rate map. Figure 4 shows that the $69.1 \%$ of respondent affordable to paid RM 50.00 per month, $12 \%$ of respondent affordable to paid RM 300 and $18.9 \%$ not willing to pay. Survey results shows that $69.1 \%$ affordable to pay RM 70.00 per month for premium insurance rate in high risk area.

In these study, prorate from affordable to pay are used and the insurance premium rate for high risk area are suggested to pay RM 140.00 per month and will be reduced $10 \%$ for medium risk area. Therefore, for area with considered as high-risk area need to pay RM 1680.00 per month and medium risk area need to pay RM 1512.00 per month. However, the insurance company can offer the community to add their premium flood insurance coverage base on the type of house, material and electrical appliance. Flood insurance rate map are published and shows as Figure 9.

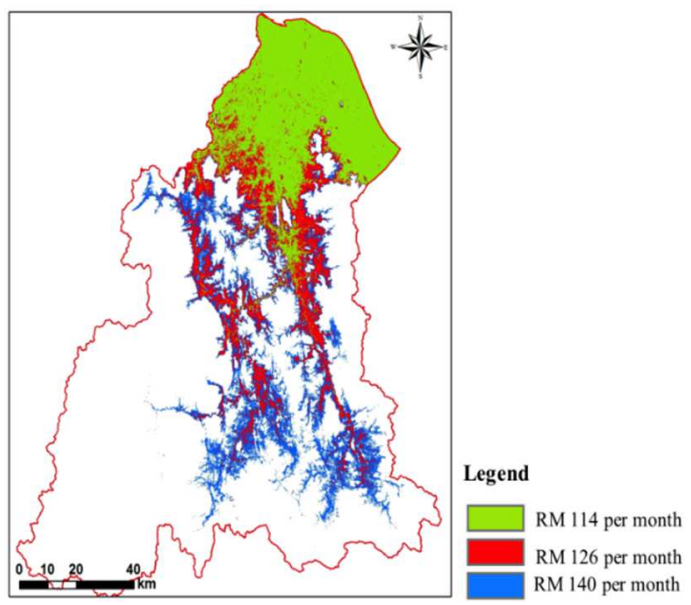

Fig. 9. Flood insurance rate map

\section{Conclusion}

Pre-disaster financial instrument as non-structural mitigation measures know as flood insurance rate map have been successfully develop using integration of ALOS PALSAR 2, ASTER GDEM and socio-economic survey. In addition to the flood insurance rate map, are developed to promote insurance programme which creates financial incentives for communities to lower 
flood insurance premiums rate. This tool is aimed to reduce the impact of flood on private and public structures and to be adopt and enforce in Sensitive Environmental Area that included as guideline in National Physical Plan.

This study is being supported by Ministry of Education Malaysia through F2015101FRGS and Tenaga Nasional Berhad through TNB Direct Fund U-TS-CR-17-01. Authors would like to thanks to Vision Tech Incorporated (VTI), Tsukuba Japan for ALOS PALSAR 2 imagery data. All undergraduates, postgraduate i.e. Wan Mohd Zainuddin, Mohd Syamzari, Muhammad Izzat and research engineer i.e. Ayisy Hafiy, Hafisham Othman and FatenSyaira that give support during our socio-economic survey assessment study in Kelantan and integration of flood hazard map in ArcGIS online during the development of flood insurances rate map system.

\section{References}

1. Keizrul, A. Floods in Malaysia, available at: http://www.icharm.pwri.go.jp/publication/jan 2022 2004 ws/ pdf output/ abdullah.pdf (3 March 2015)

2. Ho, J. C. Coastal Flood Risk Assessment and Coastal Zone Management Case Study of SeberangPerai and Kuantan Pekan in Malaysia. Erasmus Mundus Master's Thesis in Insurance against Natural Disasters, Joseph Henry Press, Washington DC, 2009)

3. Aliagha. U. G., Jin. T. E., Choong. W. W., M. NadzriJaafar, and Ali. H. M. 2014. Factors affecting flood insurance purchase in residential properties in Johor, Malaysia. Nat. Hazards Earth Syst. Sci., 14, 3297-3310. (2014)

4. Kryžanowski. A., Brilly. M, Rusjan. S, and Schnabl. S. 2014. Review Article: Structural flood-protection measures referring to several European case studies. Nat. Hazards Earth Syst. Sci., 14, 135-142. (2014).

5. Walker G., Tweed F., and Whittle R. A framework for profiling the characteristics of risk governance in natural hazard contexts. Nat. Hazards Earth Syst. Sci., 14, 155-164 (2014)

6. Thieken. A. H., Mariani. S., Longfield. S., and Vanneuville. W. Preface: Flood resilient communities - managing the consequences of flooding. Nat. Hazards Earth Syst. Sci., 14, 33-39. (2014)

7. Kreibich, H., Christenberger, S., and Schwarze, R.: 2011. Economic motivation of households to undertake private precautionary measures against floods, Nat. Hazards Earth Syst. Sci., 11, 309-321, (2011)

8. Kjellgren. S. Exploring local risk managers' use of flood hazard maps for risk communication purposes in Baden-Wurttemberg. Nat. Hazards Earth Syst. Sci., 13, 1857-1872. (2013)

9. Bubeck, P, Botzen, W. J. W., and Aerts, J. C. J. H. A review of risk perceptions and other factors that influence flood mitigation behaviour, Risk Anal., 32, 1481-1495, (2012)
10. Alexakis. D. D., Grillakis. M. G., Koutroulis. A. G., Agapiou. A., Themistocleous. K., Tsanis. I. K., Michaelides. S., Pashiardis. S., Demetriou. C., Aristeidou. K., Retalis. A., Tymvios. F., and Hadjimitsis. D. G. GIS and remote sensing techniques for the assessment of land use change impact on floodhydrology: the case study of Yialias basin in Cyprus. Nat. Hazards Earth Syst. Sci., 14, 413-426, (2014)

11. Jonathan Ali Ogwuche and Ibochi Andrew Abah 2014. Assessment of Flood Disaster Vulnerability for Flood Insurance Programme in Part of Makurdi Floodplain, Benue State, Nigeria. Donnish Journal of Ecology and the Natural Environment. Vol 1(1) pp. 001-005 December. (2014)

12. Erdlenbruch, K., Thoyer, S., Grelot, F., Kast, R., Enjolras, G. Risk-sharing in the context of the French Flood Prevention Action Programmes. J. Environ. Manage. 91, 363-369, (2009)

13. Merz, B., Kreibich, H., Schwarze, R., Thieken, A. Assessment of economic flood damage. Nat. Hazard. Earth Syst. Sci. 10, 1697-1724, (2010)

14. Osiel G. D., Mavra S., Gianluca P., Luca P., Phoebe K., Pedro D., Benedicte R., Nabil T., Francois H., and Edmund P. R. Promoting resilient economies by exploring insurance potential for facing coastal flooding and erosion: Evidence from Italy, Spain, France and United Kingdom. Coastal Engineering, 87, 183 -192, (2014)

15. Foudi, S., Oses-Eraso, N. Flood risk management: assessment for prevention with hydro-economic approaches in Markandya, A., Galarraga, I., Sainz de Murieta, E. (Eds.), Routledge Handbook of the Economics of Climate Change Adaptation. Taylor \& Francis (2014)

16. Dutta, D., Herath, S., Musiake, K. A mathematical model for flood loss estimation. J. Hydrol. 277, 24 49, (2003).

17. Penning-Rowsell, E., Johnson, C., Tunstall, S., Tapsell, S., Morris, J., Chatterton, J., Green, C. The Benefits of Flood and Coastal Risk Management: A Handbook of Assessment Techniques. Middlesex University Press (2005)

18. Barbier, E.B., Baumgartner, S., Chopra, K., Costello, C., Duraiappah, A., Hassan, R., Kinzig, A., Lehman, M., Pascual, U., Polasky, S., Perrings, C. The Valuation of Ecosystem Services in Naeem, S., Bunker, D., Hector, A., Loreau, M., Perrings, C. (Eds.), Biodiversity, Ecosystem Functioning, and Human Wellbeing: An Ecological and Economic Perspective. Oxford University Press, Oxford, UK, 248-262, Chapter 18, (2009)

19. Bremond, P., Grelot, F., Agenais, A. L. Economic evaluation of flood damage to agriculture - review and analysis of existing methods. Nat. Hazard. Earth Syst. Sci. 13, 2493-2512, (2013)

20. Merz, B., Thieken, A.H., 2005. Separating natural and epistemic uncertainty in flood frequency analysis. J. Hydrol. 309, 114-132, (2005).

21. Merz, B., Thieken, A.H..Flood risk curves and uncertainty bounds. Nat. Hazards, 51, 437-458 (2009) 
22. Merz, B., Kreibich, H., Thieken, A.H., Schmidtke, R. Estimation uncertainty of direct monetary flood damage to buildings. Nat. Hazard. Earth Syst. Sci. 4, 153-163, 2004. Merz, B., Kreibich, H., Schwarze, R., Thieken, A. Assessment of economic flood damage. Nat. Hazard. Earth Syst. Sci. 10, 16971724, (2010) 